\title{
The ets Genes in Cells and Viruses: Implications for Leukemias and Other Human Diseases
}

\author{
TAKIS S. PAPAS, ${ }^{a}$ NARAYAN K. BHAT, ${ }^{a}$ \\ THOMAS T. CHEN, ${ }^{b}$ GARRETT DUBOIS, ${ }^{c}$ \\ ROBERT J. FISHER, ${ }^{a}$ SHIGEYOSHI FUJIWARA, ${ }^{a}$ \\ LOUIS J. PRIBYL, ${ }^{a}$ NICOLETTA SACCHI, ${ }^{a}$ ARUN SETH, ${ }^{d}$ \\ STEPHEN D. SHOWALTER, ${ }^{c}$ DENNIS K. WATSON, ${ }^{a}$ \\ MARTIN ZWEIG, ${ }^{c}$ AND RICHARD ASCIONE ${ }^{a}$ \\ ${ }^{a}$ Laboratory of Molecular Oncology \\ National Cancer Institute \\ Frederick Maryland 21701-1013 \\ ${ }^{b}$ Department of Biology \\ The Johns Hopkins University \\ 34 th and Charles Streets \\ Baltimore, Maryland 21218 \\ ${ }^{c}$ Nucleic Acid and Protein Synthesis Laboratory \\ Program Resources, Inc. \\ P. O. Box B \\ Frederick, Maryland 21701-1013 \\ ${ }^{d}$ Bionetics Research, Inc. \\ P. O. Box B \\ Frederick, Maryland 21701-1013
}

\begin{abstract}
One of the most interesting scientific challenges of our time has been to understand the spectrum of oncogenic changes necessary to commit normal cells to a neoplastic life-style. On the molecular level, this enigmatic quest centers upon our understanding the essential ingredients needed to control cell growth (and its coordinate processes), as well as to maintain the normal differentiated pattern of expression for specific genes. Another, perhaps simpler, approach to this difficult challenge would be to examine the genetic changes resulting from the introduction of a known acute retroviral transforming sequence capable of eliciting a malignant cellular phenotype in vitro and neoplastic disease in vivo. Through the application of the powerful technique of recombinant technology application in the study of model retrovirus systems, the precise DNA sequences responsible for cellular transformation have been identified and studied. Thus, the employment of acute retroviruses as tools to identify a select cohort of genes capable of malignant transformation has been most fruitful. More important, from this study came a realization that this category of genes, the viral oncogenes, were capable of establishing and maintaining the transformed state, as well as the recognition that these genes were derivatives of a limited population of normal cellular genes, the proto-oncogenes, that can be captured and modified by the viral transduction process. These homologous genes, now numbering several dozen, are found distributed in the genomes of almost all vertebrates and of some invertebrate species, as well as of a few more primitive single-cell species.
\end{abstract}


Some general conclusions have been evolving from the study of these viral oncogenes and their normal cellular homologs, namely, that the transforming variants are damaged, frequently truncated versions of the normal cellular proto-oncogenes.' Thus, this avenue of study provides scientists and oncologists with some direction and serves to focus research at many levels. These investigations, be they biochemical, genetic or clinical have pointed to common cellular denominators implicating these oncogenes and proto-oncogenes and their products in certain critical processes in which they may be involved. ${ }^{2}$ Added to these investigations is the cumulative evidence that these oncogene homologs are located at critical sites on human chromosomes. These loci may be subject to nonrandom chromosomal aberrations and thus be involved in quantitative or qualitative changes associated with human neoplasia and other diseases. $^{3}$

Studies in our laboratory have centered on the use of retroviruses as tools to investigate avian acute leukemia virus transforming genes and their normal cellular counterparts. As a result of these studies, we have come to realize that specific viral oncogenes like those belonging to the avian erythroblastosis virus, E26, not only contribute significantly to a growing body of information related to that class of conserved cellular genes that may be important in tumorigenesis, but may also be functionally important in cell growth and, as such, relevant to other human diseases."

The transforming sequences of the avian acute leukemia virus, E26, contain two distinct oncogenes, $v-m y b^{\mathrm{E}}$ and $v$-ets, fused together with segments of the viral structural genes, $\Delta-$ gag and $\Delta-e n v$, to constitute the $5.7-$ kilobase $(\mathrm{kb})$ genome of this replication-defective retrovirus ${ }^{5,6}$ (FIG. 1).

The E26 virus induces both myeloblastic disease and erythroblastosis in vivo. The myeloid oncogenic property that the E26 virus and avian myeloblastosis virus (AMV) share in common is thought to be due to their common transduction of myb coding domains. The erythroblastosis pathology of E26 virus, on the other hand, may be due to the presence of the unique v-ets domain or perhaps to a synergistic effect of both oncogenes. The nucleotide sequence of a $2.5-\mathrm{kb}$ ets-containing region of E26 DNA reveals a contiguous gag-myb-ets open reading frame encoding a $135-\mathrm{Kd}$ protein, p135, a product found in E26 viral-transformed cells. ${ }^{5.7}$

To study the genetic organization and origin of the ets oncogene, our laboratory has cloned and studied the molecular details of the proto-ets gene originating from the avian host (i.e., the chicken), as well as compared these proto-ets genes in a variety of other species of animals, including man. ${ }^{8}$ To facilitate our investigations on the comparison of chicken proto-ets genes, with the viral ets genes, overlapping clones were isolated and digested with different restriction enzymes and then hybridized with specific segments of v-ets probes and aligned. Nine presumptive exons were thus defined by their homology to v-ets, each exon delineated by consensus splice-acceptor and splice-donor sequences. These cellular exons ranged in size from 82 to 257 base pairs, while the introns are seen to be quite variable, ranging from $0.1 \mathrm{~kb}$ to greater than $40 \mathrm{~kb}$. The v-ets homologous chicken sequences are seen to be spread over $60 \mathrm{~kb}$ of genomic DNA, making it one of the most dispersed proto-onc genes characterized thus far (FIG. 2). As expected, since the chicken is the retroviral host organism, there is a very high conservation of the majority of ets sequences found in the virus; all but three nucleotides are unchanged from chicken to virus. Moreover, the chicken and the viral genes are not coterminal. ${ }^{9}$ However, this observation is consistent with our data obtained from human genomic and cDNA clones demonstrating that the human ets-2 and $v$-ets genes are not coterminal. ${ }^{10}$

Using segments of the v-ets oncogene as probes, we have been able to identify proto-ets sequences in the human genome, as well as in the genome of other mammals (feline and murine). In humans there are two distinct v-ets homologous loci, Hu-ets-1 
and $\mathrm{Hu}-\mathrm{ets}-2$. These human loci were found to be discontiguous unlike that of chicken and avian E26 virus except for a small region of overlap. ${ }^{10}$ On the basis of structural organization and molecular sequence comparisons, we have defined the $5^{\prime}$ portion of the viral ets oncogene as ets-1, and the $3^{\prime}$ portion of the viral ets oncogene as ets -2 . These proto-ets domains in mammals map to separate loci on homologous, but distinctly different chromosomes. Thus, the $5^{\prime} \mathrm{v}$-ets homologous region defined above locates in man (i.e., human proto-ets-1 gene [Hu-ets-1]) on chromosome 11; its feline and murine counterparts locate on chromosomes (f)Dl and $(\mathrm{m}) 9$, respectively. The $3^{\prime}$ $v$-ets homologous region similarly locates in man (i.e., human proto-ets-2 gene [Hu-ets-2]) on chromosome 21, while the feline and murine homologs are on chromosome (f)C2 and (m)16, respectively. Each of the ets genes characteristically belong to homologous syntenic groups in Mammalia with respect to other genetic markers (FIG. 3). ${ }^{11}$

Scrutiny of the nucleotide sequences of the cloned human proto-ets sequences with their viral ets homolog reveals a striking level of conservation. The Hu-ets-l and Hu-ets-2 genes, respectively, possess a $98 \%$ and $95 \%$ homology with their viral counterparts, comparing at the amino acid level. This homology would place these genes among those highly conserved between cellular and viral oncogene sequences. Most surprising, however, has been our observations on the cloned ets-2 homologous sequences in Drosophila; this homolog, containing only the last two exons of ets, shows over a $90 \%$ conservation at the amino acid level compared with the $\mathrm{Hu}-e t s-2$ gene-a

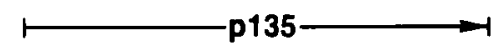

E26 RNA (5.7 Kb)

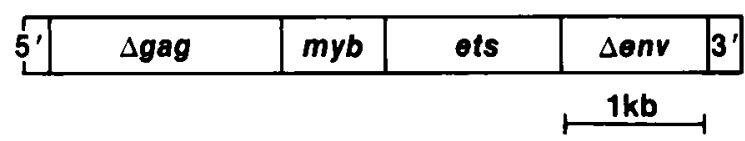

FIGURE 1. Genomic organization of the avian acute transforming virus, E26.

remarkable level of conservation; also the highest thus far noted for any protooncogenes so widely separated on the evolutionary scale (FIG. 4). ${ }^{12}$

Our laboratory has been able to determine that both the human ets-1 and ets-2 loci are transcriptionally active and are differentially expressed; the $\mathrm{Hu}$-ets-1 gene is transcribed as a single 6.8-kb mRNA, while the Hu-ets-2 gene is expressed as three distinct species of RNA, sized 4.7, 3.2 and $2.7 \mathrm{~kb}$. By contrast, the chicken c-ets mRNA is five times more complex $(7.5 \mathrm{~kb})$ than the viral ets genomic RNA $(1.5 \mathrm{~kb})$.

Interestingly, the viral ets contains in its $5^{\prime}$ domain, the v-ets-1 region, 224 nucleotides not found transcribed in chicken thymus. Thus, not only has the E26 virus captured a much smaller portion of the chicken ets gene, but it has also transduced a substantial portion of cellular noncoding sequences that are now able to be incorporated into the E26 viral-encoded product. ${ }^{13}$ These molecular events, in addition to the carboxy terminal differences noted above, probably have important functional implications for the retroviral transforming protein, as well as its biochemical role in cellular transformation.

As stated above, the products of the mammalian ets-1 and ets-2 genes appear to be differentially expressed ${ }^{14}$ and we shall present evidence later in this report that their encoded protein products are localized predominantly in separate subcellular compartments. ${ }^{15}$ Specifically, the human ets-1 gene-encoded protein seems to locate preferentially in the cytoplasm, while the human ets-2 gene-encoded protein appears in the 


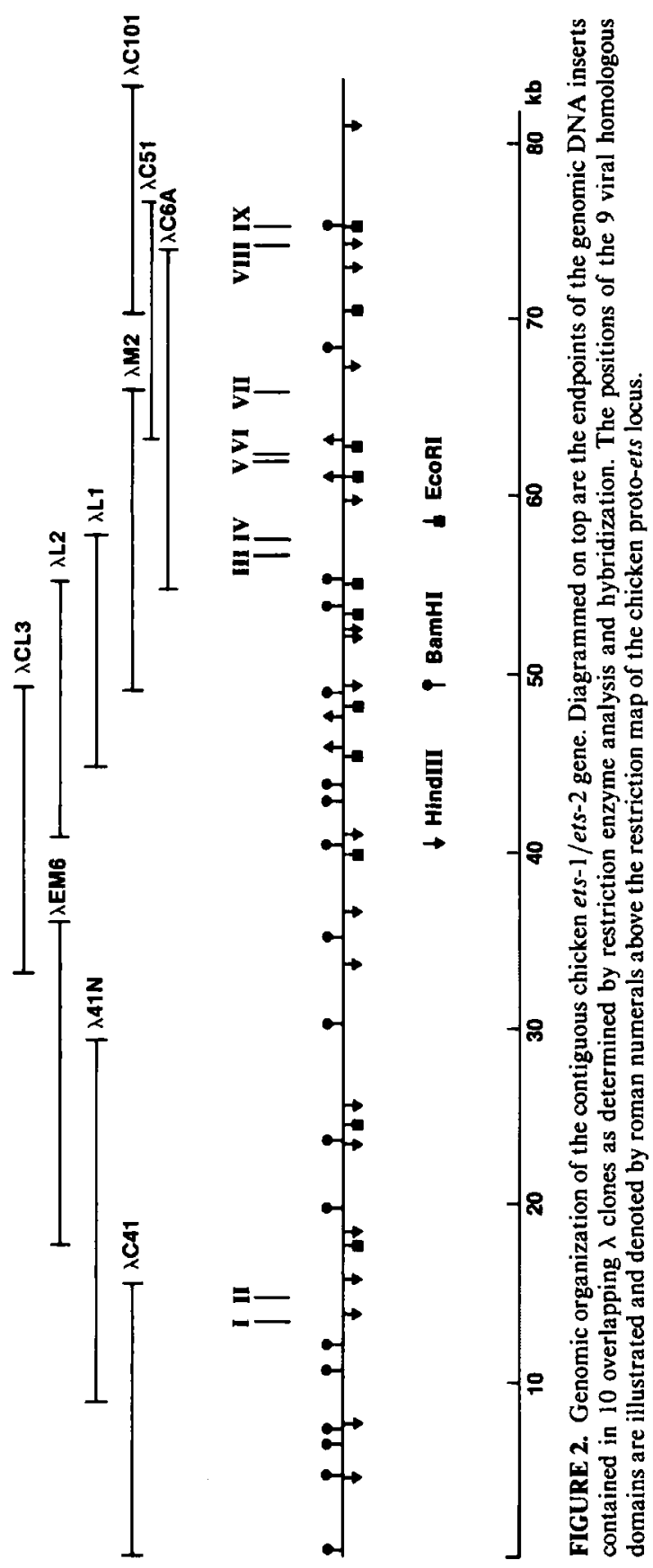


nucleus. It is known that a number of proto-oncogene products, particularly of the nuclear family, have been implicated in cellular systems as regulators and effectors of proliferation.

To investigate the possibility that the ets genes may be involved in such growthrelated processes we studied its expression in a variety of murine tissue, including germ-line tissue (testis). The expression of $e t s-1$ was much higher in cells and tissue of hematopoietic origin than in other tissue, including hepatic tissue. The murine expression of $e t s-1$, as characterized by multiple species of mRNA, 5.3, 4.0, 2.5 and 2.0 $\mathrm{kb}$ in size, was found to be actively transcribed in both young and old thymus tissue. By contrast, the product of the murine ets-2 gene, characterized by a $3.5-\mathrm{kb}$ transcript, was preferentially expressed in a variety of proliferating young tissue by contrast to less proliferative older tissue. This relative difference was most clearly evident in testis tissue, where ets-2 mRNA synthesis was maximal in 8-day-old preparations, compared to older (42-day) germ-line-derived samples (FIG. 5). This observation suggested that the proliferative state of the tissue may be relevant to the expression of ets -2 . In fact, for these age groups, even for the exception noted, the abundant ets- 2 expression in thymus tissue tended to prove the rule, since thymocytes are normally in a highly proliferative state. By contrast, there was significant lower expression of ets-2 in terminally differentiated adult brain, liver, kidney, lung and heart tissue, which were compared with appropriate controls, using an $\alpha$-tubulin gene probe. Thus, it appeared from these data that the ets genes are differentially expressed and subject to variable regulation in proliferating tissue (FIG. 5) ${ }^{14,16}$ Studies on the expression of ets-1 and ets-2 gene-encoded protein also substantiated these observations (FIG. 6). Antisera raised against an ets-2 domain specific oligopeptides and bacterially-expressed ets proteins detected two ets gene proteins (56 KDa and $30 \mathrm{KDa}$ ), which appeared to correlate very well with the ets- 2 mRNA expression observed in young and adult thymus. The thymus is the only adult tissue examined that had both ets-2 RNA and protein expressed at a high level when compared to nonhematopoietic tissue. Unlike the 56-KDa ets-2 protein, there was a selected species not detected by immunoprecipitation, suggesting that this $30-\mathrm{Kd}$ protein may represent some cross-reacting species.

To further elucidate the linkage of ets-2 gene expression with cellular proliferation, we studied hepatically regenerating tissue as a model in-vivo system. It is known that when two thirds of the liver mass is removed by surgery in the mouse, ${ }^{17}$ the remaining liver cells proliferate and organ mass and function is completely restored within 5 to 6 days posthepatectomy. ${ }^{18}$ FIGURE 7 depicts a result of our Northern transfer analysis of poly A-selected RNA obtained at various times postpartial hepatectomy. Data shows clearly that the ets-2 mRNA peaks 4 hrs following surgery, and returns to basal levels within $24 \mathrm{hrs}$. Densitometric scanning studies of the 4-hr sample of ets-2 mRNA, following partial hepatectomy, shows a 10 -fold increase above basal levels found in sham controls or in adult liver tissue. It should be kept in mind that these are minimal values, since the entire liver was used to prepare RNA rather than the specific regenerated tissue. Clearly, the induction of ets-2 mRNA is due to the partial hepatectomy, and not the stress induced by surgery, since only basal levels of ets-2 mRNA can be detected in sham control samples. The amount of RNA applied in each lane was the same, since there were equivalent levels of rRNA present in all samples tested.

During the course of liver regeneration DNA synthesis peaked at $48 \mathrm{hrs}$ following surgery, consistent with other published reports; ${ }^{17}$ thus, the maximal expression of ets-2 occurring at $4 \mathrm{hrs}$ after hepatectomy is well before that of DNA synthesis. Hepatic ets-1 expression, unlike that of ets-2, was not detected following partial hepatectomy at any of several time points spanning one round of DNA replication, further corroborating that these genes are differentially expressed. 


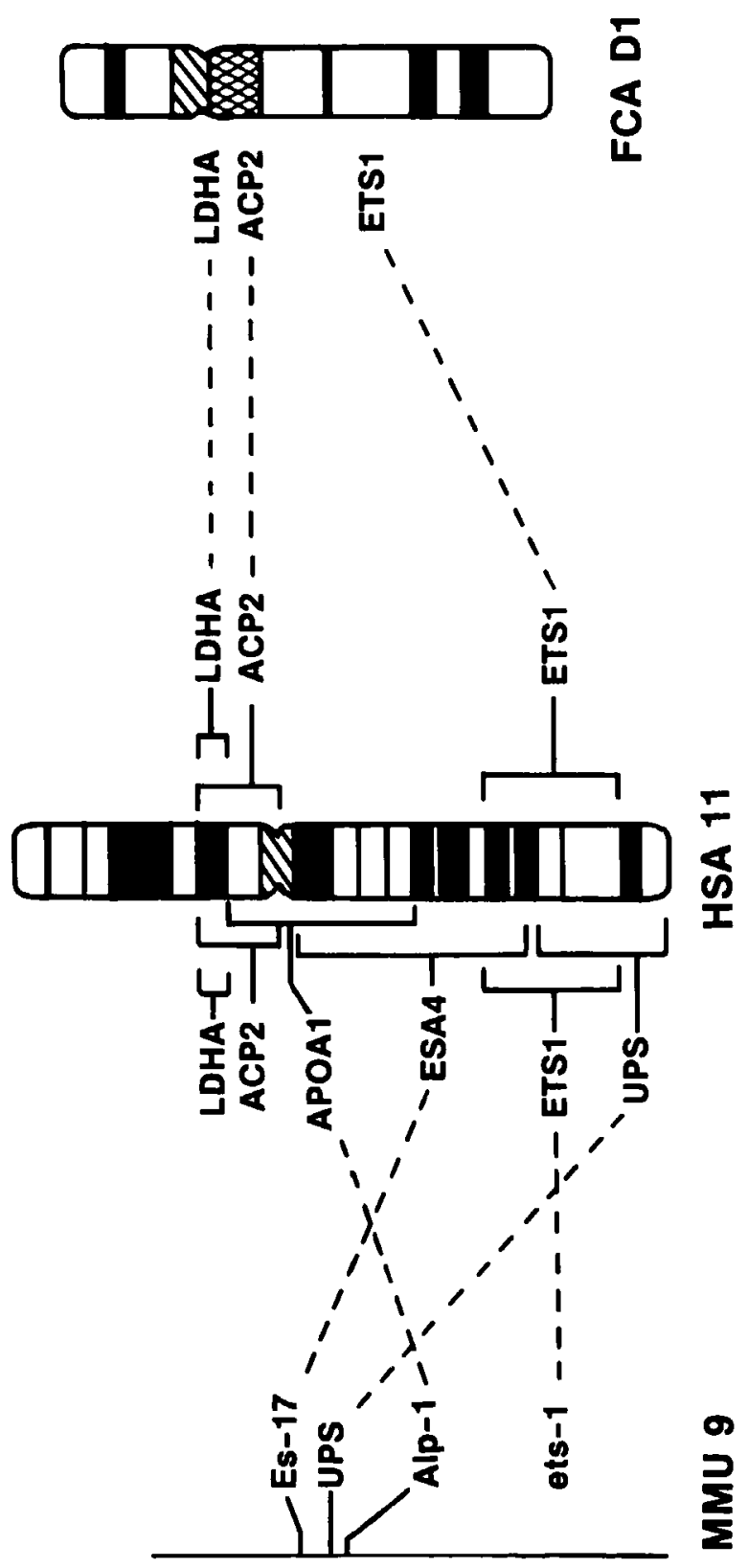




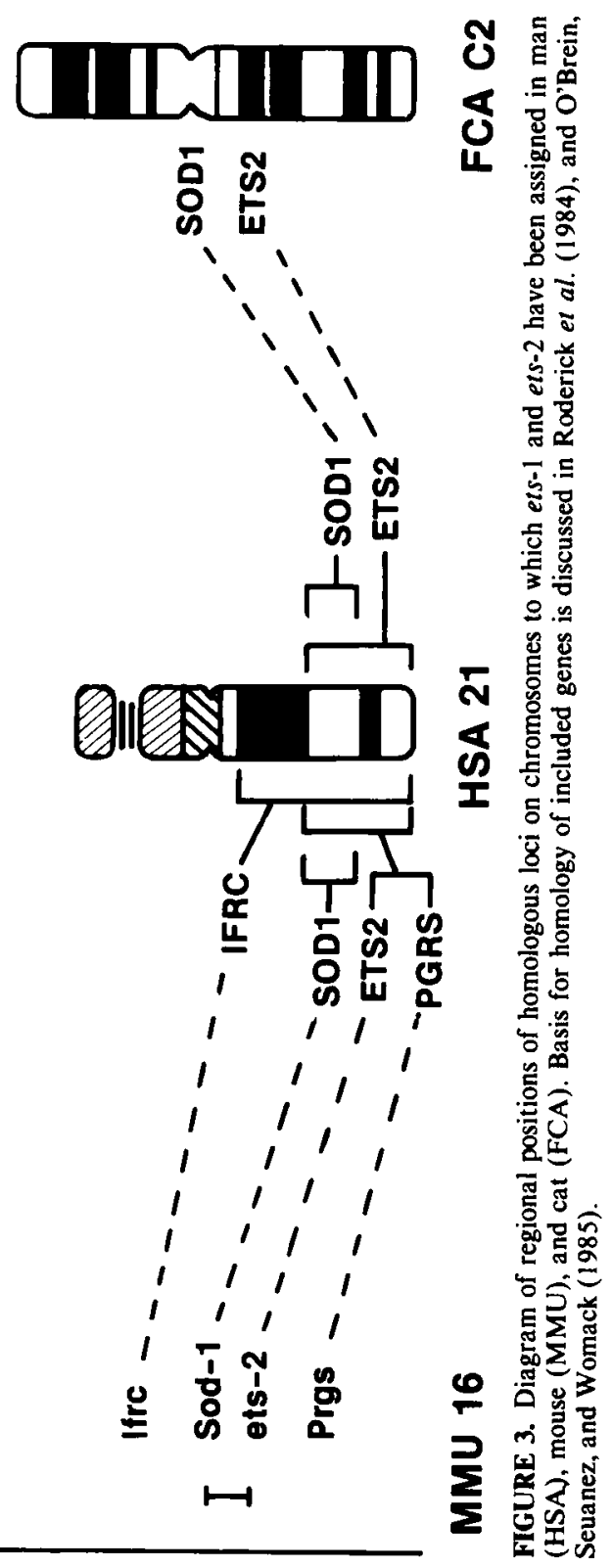




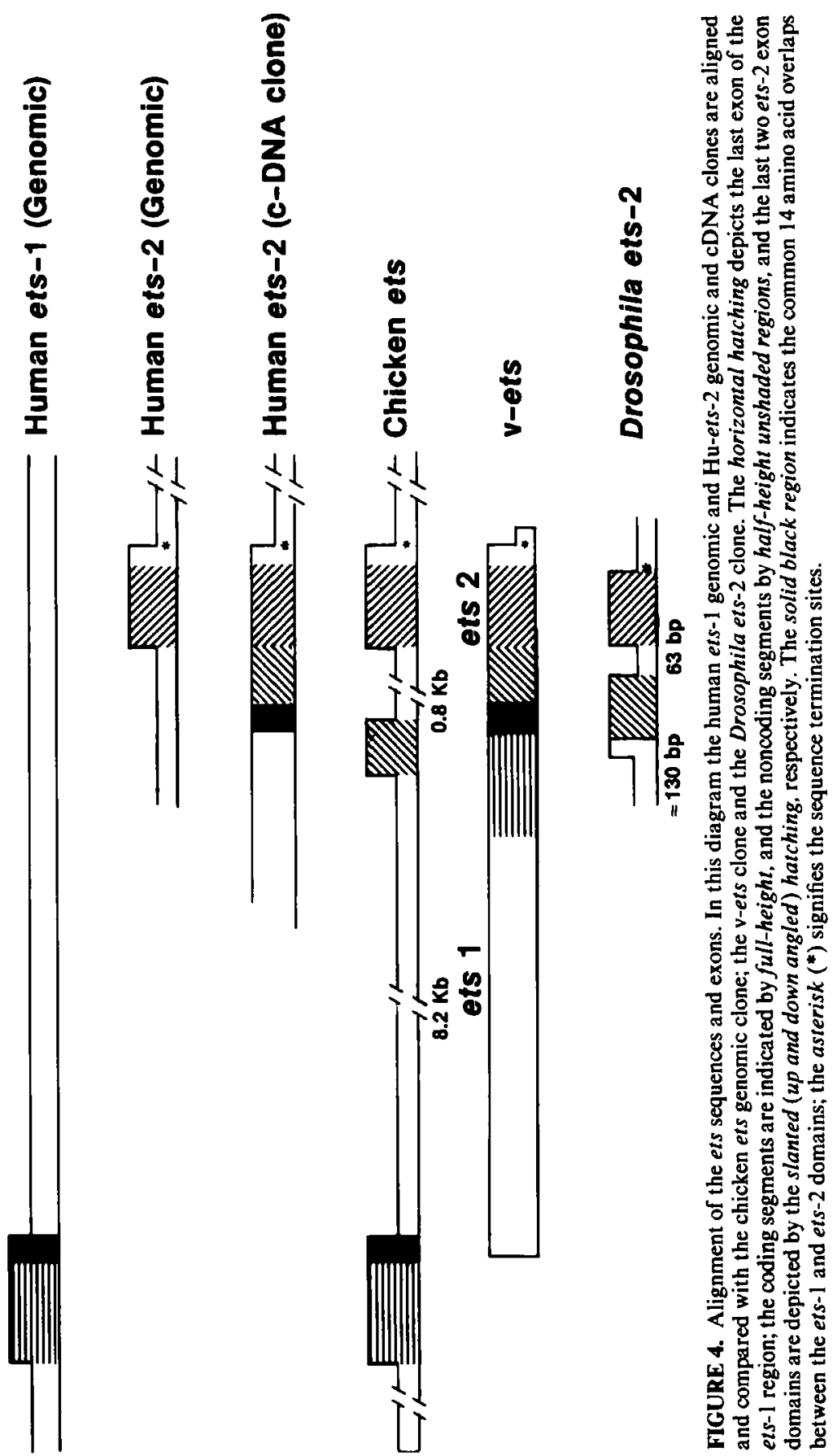




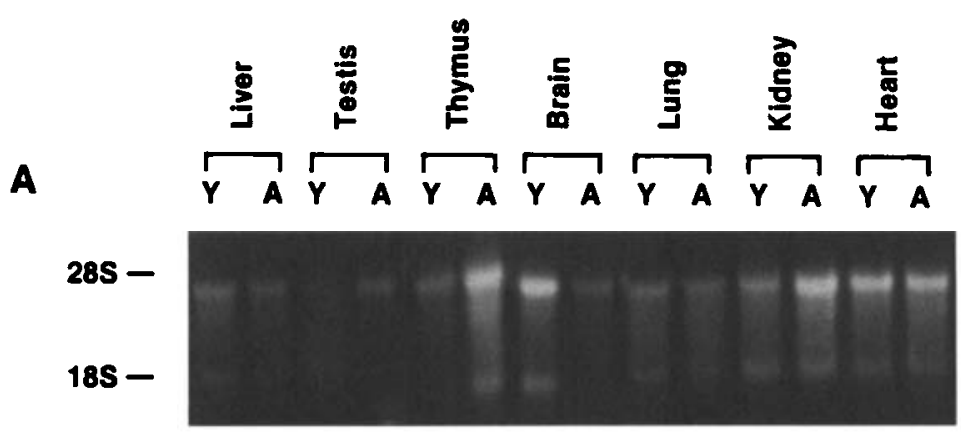

B

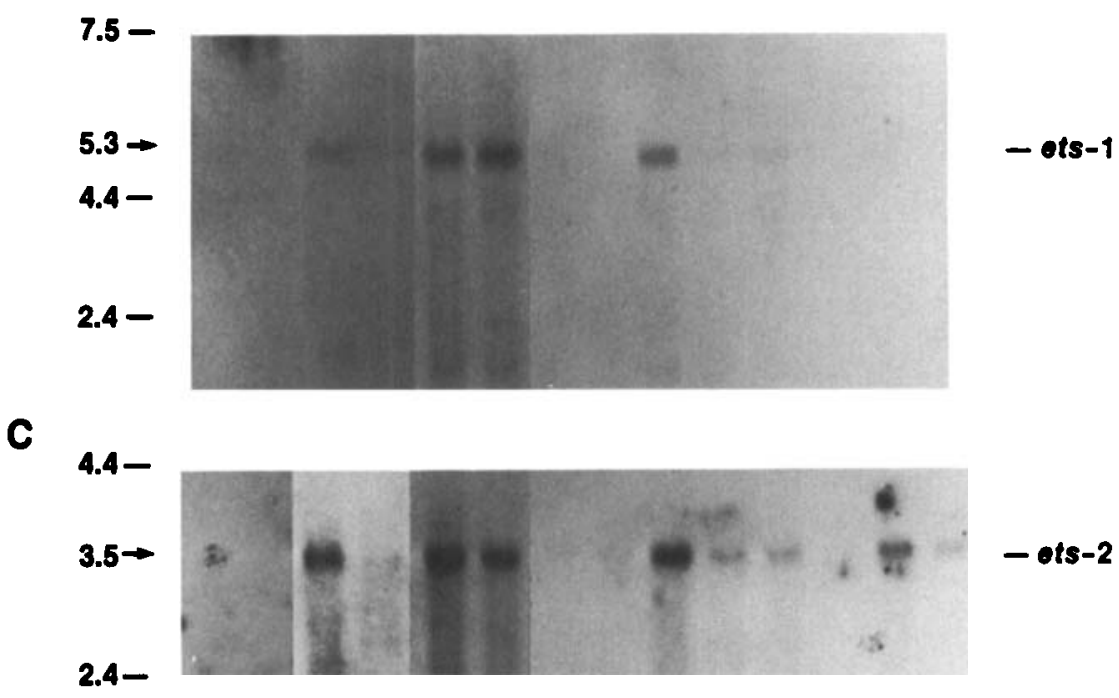

FIGURE 5. Distribution of ets mRNA in Young (Y) and Adult (A) tissues; (A) Ethidium bromide stained pattern of the residual rRNA. Three micrograms of poly $A^{+}$RNA was fractionated on denaturing agarose min-gel after the electrophoresis fractionated RNAs were stained with ethidium bromide. (B and C) Northern blot analysis of ets mRNA. Twenty micrograms of poly $\mathrm{A}^{+}$RNA from Young ( 5 to 10 day old) and Adult (5 to 6 week old) tissues were fractionated and Northern blots were probed with human ets-1-specific probe (B) or with mouse ets-2 probe (C) as described in the text. The ets-1 and ets-2 transcripts are shown by arrows. Minor transcripts are indicated by dashes. BRL RNA ladder was used as standard RNA markers and their sizes $(\mathrm{kb})$ are shown on the left hand side.

To arrange the induction of ets-2 mRNA in an ordered sequence of expression relative to other genes known to be involved in cell proliferation, we examined the kinetics of expression of several select genes. Specifically, we probed several protooncogenes: $m y c$ and $f o s$ of the nuclear family; $m h t, e r b \mathrm{~B}$ of the protein kinase family; and sis of the growth factor family. Also, we selected several non-oncogenes representing the housekeeping family, actin, tubulin, and those of a stress-related family, the heat shock protein, and a metallothionein protein. The ets -2 mRNA levels increased 10-fold in $4 \mathrm{hrs}$, returning to basal levels by $24 \mathrm{hrs}$; whereas the kinetics of 

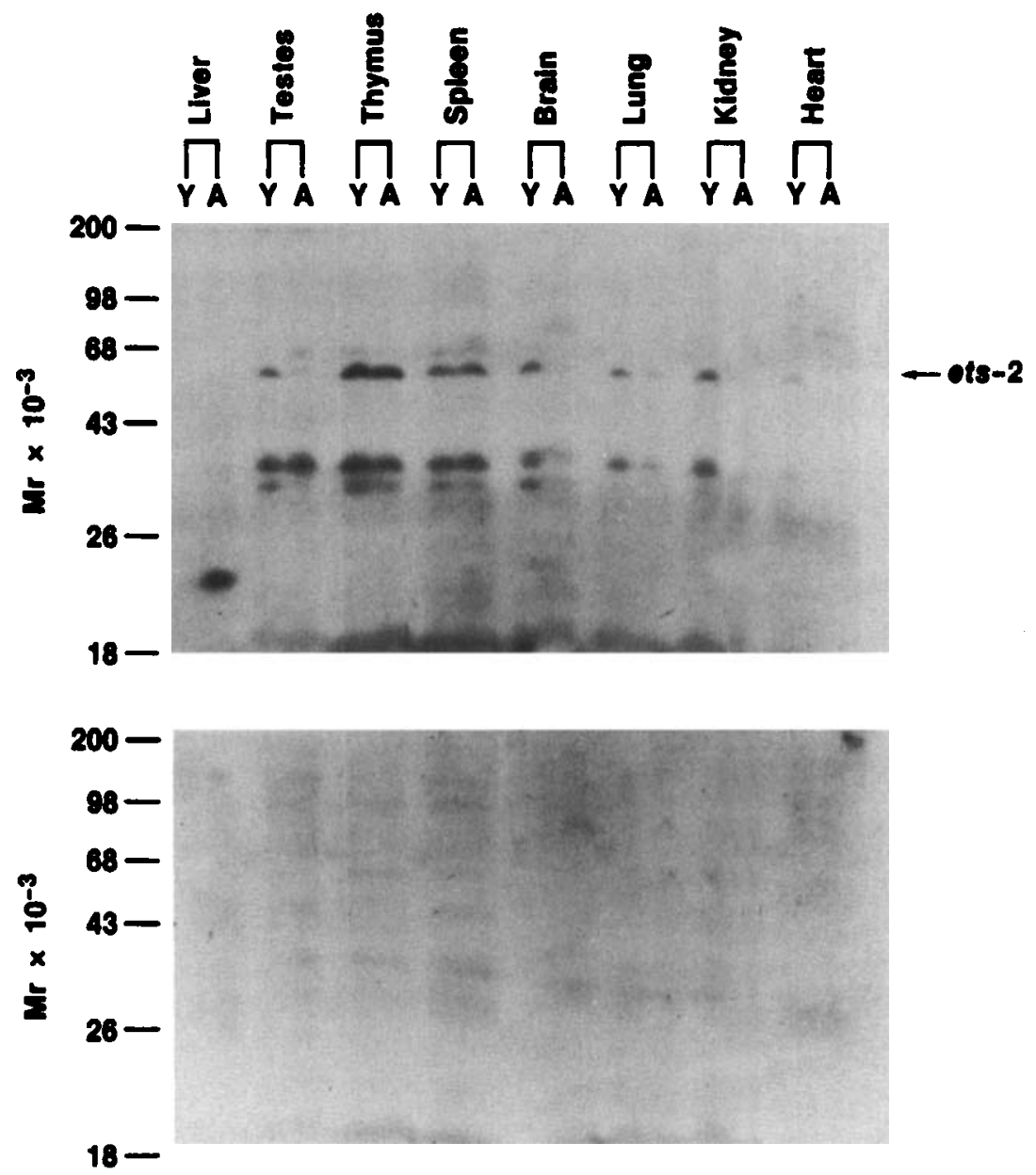

FIGURE 6. Western blot analysis of ets-2 protein in Young ( $Y$ ) and Adult (A) tissues. Two milligrams (wet/wt) tissues were solubilized in sample buffer and size fractionated on $10 \%$ polyacrylamide SDS gels. Western blots were processed in the absence (top panel) or in the presence (bottom panel) of cognate peptide as described in the text. The position of the 56-Kd putative ets-2 protein is indicated by the arrow. Standard molecular weight markers are shown on the left hand side.

$m y c$ and $r a s^{\mathrm{H}}$ mRNA induction is notably different from that of $e t s-2$. Specifically, the myc RNA level increased 3- to 4 -fold after $2 \mathrm{hrs}$ and returned to basal level by $8 \mathrm{hrs}$. By contrast, ras $^{\mathrm{H}}$ mRNA increased 2 -fold and remained elevated even after $48 \mathrm{hrs}$. The proto-oncogenes fos, $m h t$, erbB or sis-specific transcripts were not detected at different time points examined during hepatic regeneration. Note, however, that the metallothionein messenger RNAs increased more than 100-fold in both sham-operated and hepatectomized animals, reflecting the stress imposed by surgery. Actin mRNA, too, was induced, but only 10 -fold, $4 \mathrm{hrs}$ following partial hepatectomy; this course of induction was different from the $\alpha$-tubulin mRNA, which increased 2- to 4-fold after 
48 hrs. Failure to detect expression of the proto-oncogene, c-fos, which is transiently expressed, was expected, since our earliest time point sampled was $2 \mathrm{hrs}$ posthepatectomy; this is a time well past the known maxima of c-fos induction. ${ }^{19}$ Collectively, these data are in agreement with the sequential expression of nuclear proto-oncogenes that are known to induce during the transition from $G_{0}-G_{1}$ phase of the cell cycle following partial hepatectomy. ${ }^{20}$

Like other nuclear proto-oncogene mRNAs, cycloheximide was found to superin-

\section{Partial}

Hepatectomy
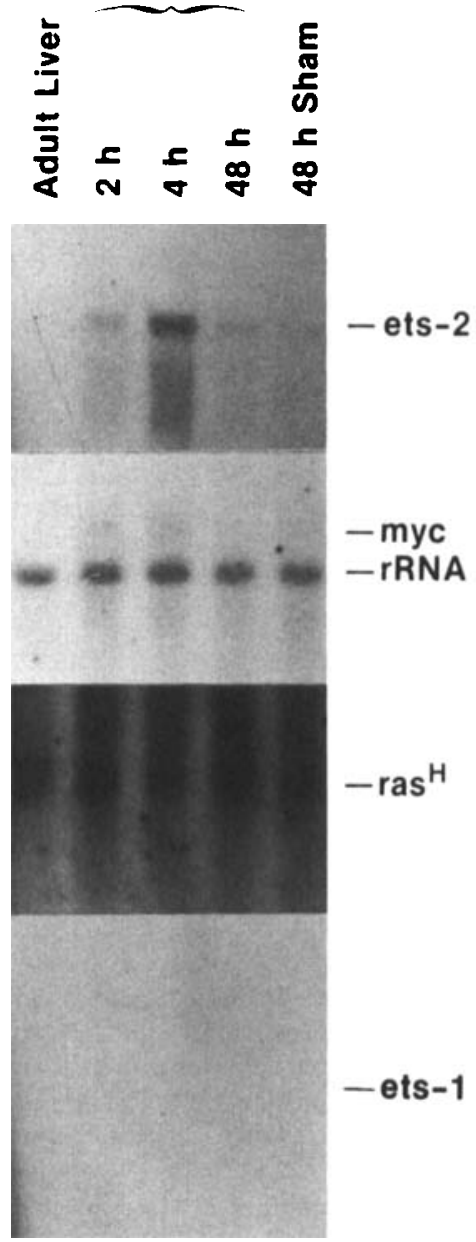

Partial

Hepatectomy
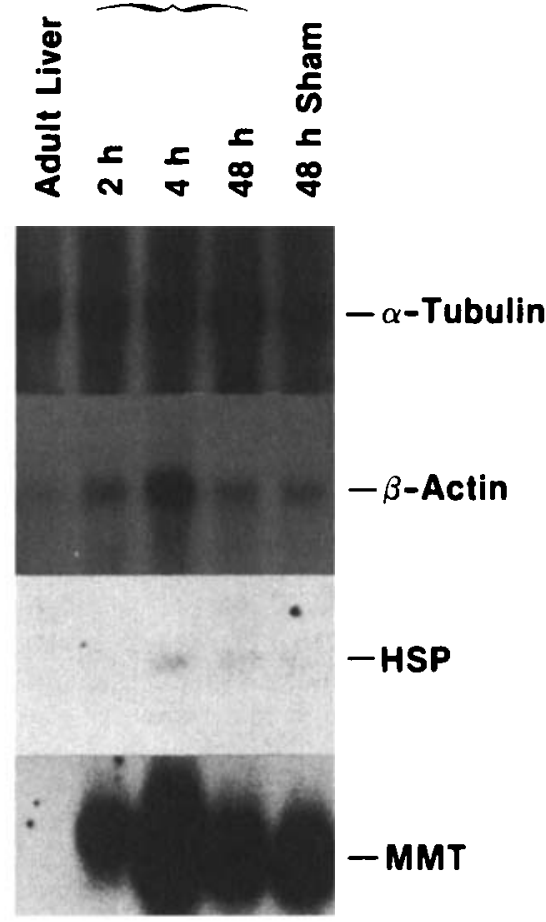

FIGURE 7. Gene expression during liver regeneration. Fifteen micrograms of poly $\mathrm{A}^{+}$ RNA from adult liver, sham control livers, and livers from partially hepatectomized animals were size fractionated and filters were probed sequentially with mouse ets-2, human ets-1, human $m y c$, v-ras ${ }^{\mathrm{H}}, \alpha$-tubulin, $\beta$-actin, heat shock protein (HSP) and mouse metallothionein (MMT) probes. Transcripts detected by these probes are indicated on the right hand side. 
duce the level of ets-2 RNA by more than 15 -fold, as well as stabilizing the ets-2 message. Partial hepatectomy amplified (20- to 40-fold) the effect of this ets-2 expression, which was not observable for the ets-1 mRNA. Myc, fos and ornithine decarboxylase (a marker for cell proliferation) also shared the same expression pattern as the ets-2 gene. Collectively, these data help establish that the et $s-2$ gene is a member of a proliferative gene family, and one that is subject to differential regulation and expression in proliferating hepatic tissue. Our data implicate the ets-2 gene as a member of the family of nuclear proto-oncogenes that is normally expressed during the early phase of hepatic regeneration and can be characterized by the following sequential expression, fos $\longrightarrow \longrightarrow$ myc $\rightarrow \longrightarrow$ ets $-2 \longrightarrow \longrightarrow \rightarrow$. We do not know as yet if these genes are obligatorily expressed in this particular sequence, or if the gene transcripts are processed at different rates and thus appear so ordered. We do know, however, that during hepatic regeneration the transcription of the ets-2 proto-oncogene does not require de-novo protein synthesis.

To summarize, our results on the studies of ets RNA in mice suggest that in murine liver both $e t s-1$ and $e t s-2$ gene expression is differentially regulated; that the ets-2 gene transcription is inducible by hepatectomy and its expression is similar to the pattern of expression noted for other nuclear proto-oncogenes, fos and myc. It logically follows that the ets-2 gene product may be associated with the transition of cells from $G_{0}$ to $G_{1}$ phase of the cell cycle and this involvement is certainly consistent with the roles postulated for other nuclear proto-oncogenes.

We have recently presented information identifying the products of the two human ets genes and their subcellular location. ${ }^{15,21}$ To accomplish this study, we developed antibodies specific for $e t s-1$ and $e t s-2$ domains. Another antibody was prepared using a synthetic oligopeptide derived from the predicted amino acid sequences of the ets common domain; a portion of this region has been highly conserved in a variety of species, ranging from Drosophila to man. ${ }^{8,12,22}$ All of these antibodies are described in the legend of FIGURE 8.

We established that these three antibodies reacted specifically with ets proteins by immunoreactive studies using extracts of transfected NIH3T3 cells infected with a murine/avian recombinant retrovirus construct containing the gag-myb-ets region of the E26 virus. The $\left[{ }^{35} \mathrm{~S}\right]$-methionine-labeled extracts of these cells were each immunoprecipitated using the three different antibodies. In all three experiments the antibodies precipitated the 135-KDa ets-containing fusion protein (FIG. 8, lanes 1, 3 and 5). Moreover, precipitation of this v-ets-encoded protein was specifically blocked by an excess amount of the respective peptide-antigen (FIG. 8, lanes 2 and 4). The pl 35 fusion protein was found only in transfected cell extracts and was also recognized by sera prepared against the avian retroviral gag protein. There is additional evidence, FIGURE 8, showing that these antibodies react with ets-specific sequences, since the $e t s$-1-specific antibody also reacted with a $v$-ets-1 protein expressed in bacteria (FIG. 8 , lane 6), and the ets-1-ets-2 common domain antibody detected a bacterially-expressed ets-2 protein product (FIG. 8, lane 8). Both reactions were immunospecific, since excess peptide totally competed the precipitation of the respective ets proteins (FIG. 8, lanes 7 and 9).

Having reported previously that ets-1 and ets-2 domains are contiguous in the avian genome, ${ }^{10}$ we had to determine whether the ets-1 and ets-2 antibodies are able to detect a singular protein in chicken tissue, using for this purpose $\left[{ }^{35} \mathrm{~S}\right]$-methioninelabeled chicken thymus cells known to express high levels of ets-mRNA. ${ }^{14}$ Not surprisingly, antibodies against the ets-1 domain and ets-1-ets-2 common domain also immunoprecipitated chicken ets-1-ets-2-encoded protein (FIG. 8, lanes 10 and 12).

To identify and characterize the human proteins derived from the ets-1 and ets -2 loci, we have utilized cell lines expressing high levels of either ets-1 or ets-2 mRNA (N. 
Bhat, unpublished observations). ${ }^{14}$ For example, $\left[{ }^{35} \mathrm{~S}\right]$-methionine-labeled Daudi cells, the Burkitt lymphoma cell line, was employed to detect the human ets-1 grotein, with our ets-1-specific antibody. As can be seen, a prominent $51-\mathrm{KDa}$ protein was detected (FIG. 9, lane 1), which was also detected using the common ets-1-ets-2 domain antibody (FIG. 9, lane 3). However, the antibody derived from the ets-2 region does not precipitate the p51 ets-1 protein (FIG. 9, lane 5).

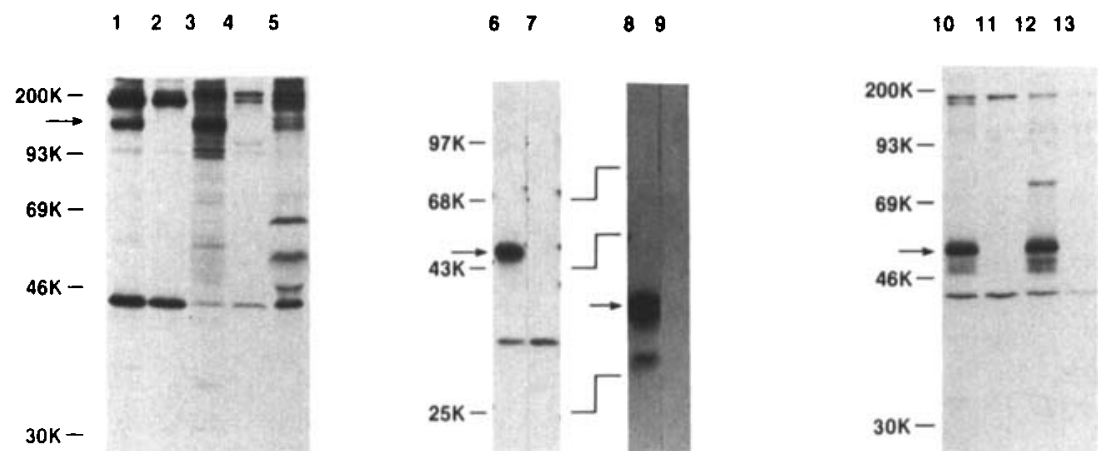

FIGURE 8. Specificity of the ets antibodies. Antibody A (ets-1-specific), Antibody B (ets-1-ets-2-specific) and Antibody C (ets-2-specific) have been described. ${ }^{15,21}$ In lanes 1 through 5, the pl 35 gag-myb-ets protein was immunoprecipitated from extracts of NIH3T3 cells transfected with the murine/avian recombinant retrovirus construct (Yuan, Q., Blair, D., Papas, T., unpublished results) that were labeled with [ $\left.{ }^{35} \mathrm{~S}\right]$ methionine $(100 \mu \mathrm{Ci} / \mathrm{ml}, 1$ h) and lysed using RIPA buffer ( $50 \mathrm{mM}$ Tris- $\mathrm{HCl}, \mathrm{pH} 7.5,150 \mathrm{mM} \mathrm{NaCl}, 0.1 \% \mathrm{SDS}, 1.0 \%$ Triton X-100, 0.5\% deoxycholate, $0.1 \mathrm{mM}$ EGTA, $1.0 \mathrm{mM}$ EDTA, $0.4 \mathrm{mM}$ phenylmethylsulfonyl fluoride (PMSF), $0.01 \mathrm{mM} \mathrm{N} \alpha$-p-Tosyl-L-lysine chloromethyl ketone (TLCK), 0.1 mM N-Tosyl-L-phenylalanine chloromethyl ketone (TPCK)). The lysate was clarified by ultracentrifugation $(100,000 \times \mathrm{g}, 30 \mathrm{~min})$ and subjected to immunoprecipitation by the rabbit antibodies prepared against the synthetic oligopeptide derived from a viral ets-1 domain (Antibody A) (lanes I and 2), the antibody directed against the common ets-1-ets-2 domain (Antibody B) (lanes 3 and 4), and the antibody directed against the ets-2 domain (lane 5). Competition is shown by preincubation with the ets-1 (lane 2) or ets-1-ets-2 (lane 4) peptides. Immunoprecipitates were fractionated by sodium dodecyl sulfate-polyacrylamide gel electrophoresis (SDS-PAGE) ( $12.5 \%$ acrylamide) and detected by fluorography. ${ }^{34,35}$ The arrow indicates the pl 35 viral protein. In lanes 6 through 9 portions of the viral ets -1 and human ets-2 proteins expressed in $E$. coli were detected by immunoblotting. ${ }^{36} \mathrm{~A}$ portion of the viral ets-1 domain (nucleotide 666-1334, ${ }^{1}$ ) and a cDNA clone of the human ets-2 gene (cDNA-14,') have been expressed in $E$. coli and are partially purified. ${ }^{13}$ The viral ets-1 (lanes 6 and 7) or human ets-2 proteins (lanes 8 and 9) were probed by Antibody $A$ (lanes 5 and 6) or Antibody B (lanes 7 and 8). Competition is shown by preincubation of antibodies with their corresponding peptide antigens (lanes 7 and 9). Arrows indicate the expressed viral ets-1 (lane 6) or human ets-2 protein (lane 8). In lanes 10 through 13 the chicken ets protein is immunoprecipitated from $\left[{ }^{3 s} \mathrm{~S}\right]$ methionine-labeled thymus cells prepared from 2-week-old chickens as described. Competition is shown for Antibody A (lanes 10 and 11) and Antibody B (lanes 12 and 13) by preincubation with the ets-1 peptide (lane 11) or ets-1-ets-2 peptide (lane 13). Relative mobilities of standard proteins are shown on the sides of each panel.

Similarly, to characterize the human ets-2 protein, we utilized the human tumor-derived cell line, COLO 320 DM. In this study, a 56-KDa protein was specifically immunoprecipitated (FIG. 9, lane 11) from labeled cell lysates using the ets-2-specific antibody. In parallel experiments the 56-KDa protein was also able to be 
precipitated with common ets-1-ets-2 domain antibody (FIG. 9, lane 8). However, it should be noted that the ets-1 specific antibody does not precipitate this 56-KDa ets-2 protein (FIG. 9, lane 6). We can thus conclude that each of these cell lines contain distinct ets-1 and ets-2 proteins, and that both these proteins can be recognized by antibodies prepared against the common ets-1-ets-2 domain. Moreover, antisera to a

\section{$\begin{array}{lllllllllll}1 & 2 & 3 & 4 & 5 & 6 & 7 & 8 & 9 & 10 & 11\end{array}$}

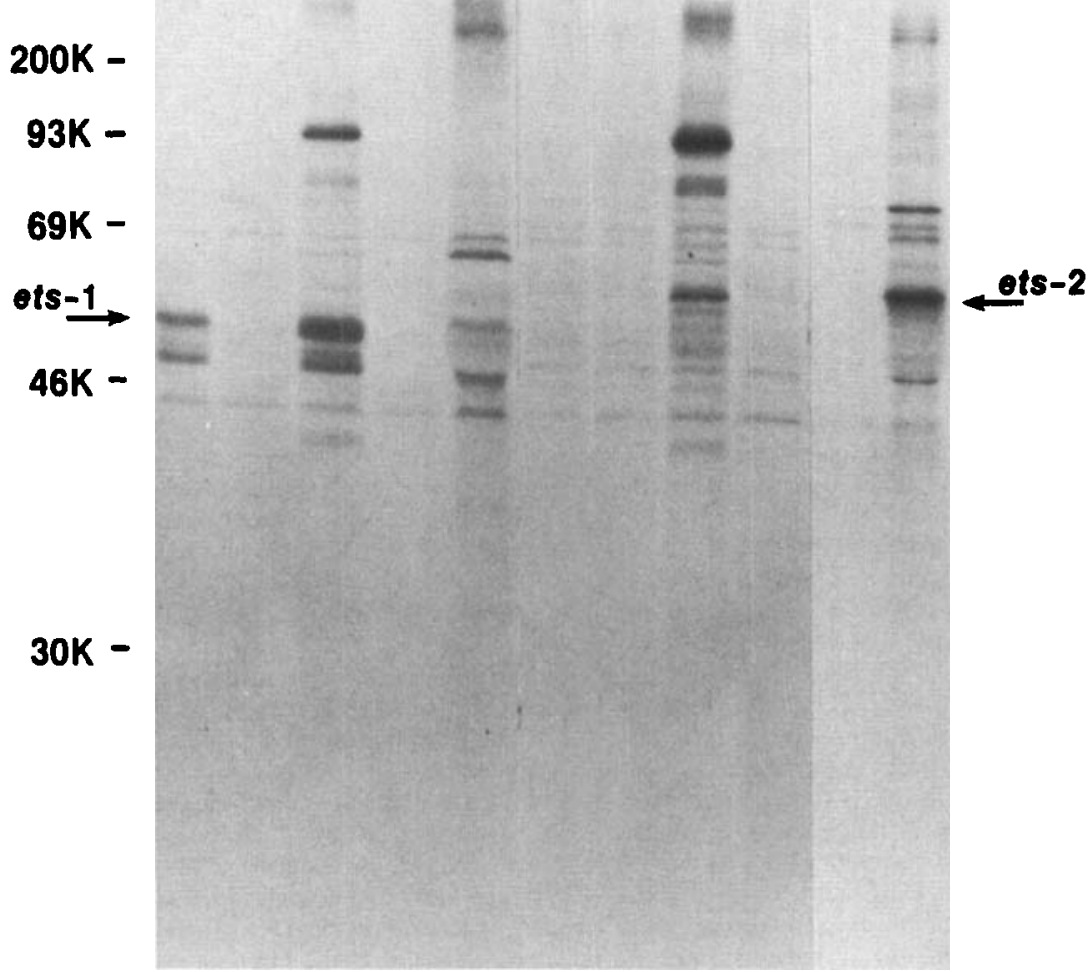

FIGURE 9. Immunoprecipitation of human $e t s-1$ and $e t s-2$ proteins. $\left[{ }^{33} S\right]$ methioninelabeled lysates from the human Burkitt lymphoma cell line, Daudi (lanes 1 through 5 ) or the human COLO 320 DM cells (lanes 6 through 11 ) were immunoprecipitated by Antibody A (lanes 1, 2,6 and 7), Antibody B (lanes 3, 4, 8 and 9), Antibody C (lanes 5 and 11) or Antibody $\mathrm{C}$ pre-immune serum (lane 10). For competition, Antibody A and Antibody B were incubated with the ets-1 or ets-1-ets-2 peptides (lanes 2, 4, 7 and 9). The samples were adjusted to $2 \times 10^{7} \mathrm{CPM}$ (TCA insoluble $\left[{ }^{35} \mathrm{~S}\right]$ methionine with RIPA buffer, immunoprecipitated and analyzed by SDS-PAGE and fluorography. The arrows indicate the human ets-1 (lanes 1 and 3 ) or the human ets-2 (lanes 8 and 11 ) proteins.

domain unique to ets-2 recognized only ets-2 protein in human cell extracts and not the ets-1 protein, while antisera to an ets-1 unique domain recognized only the ets-1 protein in human cell extracts.

Given the above observations, we felt it important to establish that the proteins 
immunoprecipitated by the different ets-2-specific antibodies were similar; this analysis was performed first by one-dimensional peptide mapping using the V-8 protease technique, which showed these maps to be essentially identical (data not shown). To demonstrate that this protein does contain an ets-2-related sequence, we employed a two-dimensional peptide-map analysis of the purified ${ }^{35} \mathrm{~S}$-labeled ets-2 protein from COLO 320 cells and compared it to the ets-2 domain product expressed in an $E$. coli vector. In these studies we found 10 polypeptides shared in common with the human p56 protein and the bacterially expressed ets-2 protein. ${ }^{15}$ This observation provided direct evidence that the human p 56 protein we analyzed shared peptides in common with the authentic ets-2-encoded protein expressed in bacteria.

As an approach towards identifying specific functions of the two distinct human $e t s$ proteins, we fractionated the ets-1 and ets-2 expressing cells, P3HR-1 and COLO 320 $\mathrm{DM}$, respectively, into subcellular components. Fractionation of $\left[{ }^{35} \mathrm{~S}\right]$-methioninelabeled COLO $320 \mathrm{DM}$ cells followed by immunoprecipitation, indicated that the human ets-2 p56 protein (large arrow, Fig. 10C, lanes 1 and 7) located exclusively in the nucleus. Other proteins immunoprecipitated (small arrows, Fig. 10C, lanes 1 and 7) have been characterized by two-dimensional peptide mapping analysis and shown to share homology with the ets-2 p56 protein. It should be pointed out that under the conditions employed for fractionation of COLO $320 \mathrm{DM}$ cells, the ets-2 protein was more tightly associated with the nuclear fraction than the "nuclear-associated" c-myc gene product. ${ }^{23}$

Similar experiments on the ets-1 protein were performed using $\left[{ }^{35} \mathrm{~S}\right]$-methioninelabeled fractionated human P3HR-1 lymphoid cells. These studies clearly demonstrated that the $51-\mathrm{KDa}$ ets-1 protein, unlike the ets-2 protein, is located exclusively in the cytoplasm (FIG. 10B, lane 3). To compare this human cellular localization of the ets protein to that of the avian cells, we labeled chicken thymus cell and fractionated them as described (FIG. 10, legend). Immunoprecipitation of the avian cell lysates shows that a 51-KDa protein, present in total cell lysates (FiG. 10A, lane 2), was equally distributed between the nuclear and cytoplasmic subfractions. This study indicated that unlike the human protein where the separated products have an ets-1 domain that enabled it to localize to the cytoplasm, and an ets-2 domain that enabled it to localize to the nucleus, the avian ets protein containing both the ets-1 and ets-2 domains is distributed between the cytoplasm and nucleus.

The human 51-KDa and the 56-KDa proteins described have been demonstrated in our laboratory to be the products of the human ets-1 and ets-2-encoded domains, respectively. Localization of these proteins, indicate different intracellular compartments for each of these human ets-encoded gene products. These segregated subcellular locations suggest further that each of these gene products performs a different function.

An examination of the putative amino acid sequences of the ets-2 gene reveals a protein domain containing a region of basic amino acid residues (gly-lys-arg-lysasn-lys-pro-lys), ${ }^{10}$ which is essentially similar to the amino acid residues of the nuclear transport signal of the large tumor antigen of simian virus 40 (pro-lys-lys-lysarg-lys-val), as well as to that of the T-antigen of polyoma virus (val-ser-arglys-arg-pro-arg-pro). It should be pointed out that for nuclear localization signals thus far reported, there is no unique sequence of amino acids specifying nuclear placement; rather there appears to be a sequence of residues encoding a cluster of positively charged amino acids sandwiched between a proline residue and other nonpolar amino acids. ${ }^{24}$ This signal region in the ets-2 domain may, in fact, prove to be functionally significant for different organisms. It is evident that in higher organisms like mammals, where the ets-1 and ets-2 domains are separate, each domain remains free to partition to its unique intracellular location. In the chicken, however, where the ets- 1 
A

$\begin{array}{lllll}1 & 2 & 3 & 4 & 5\end{array}$

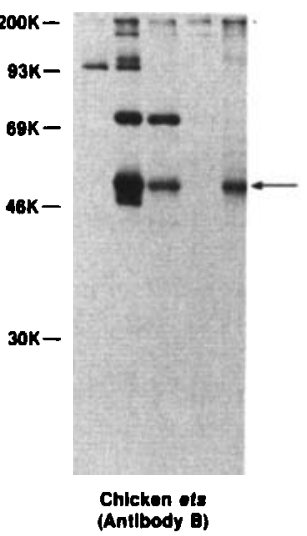

B

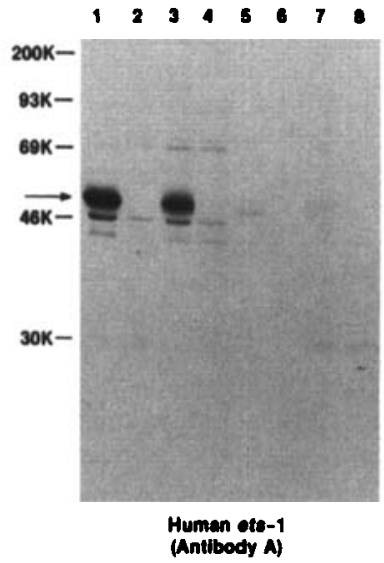

C

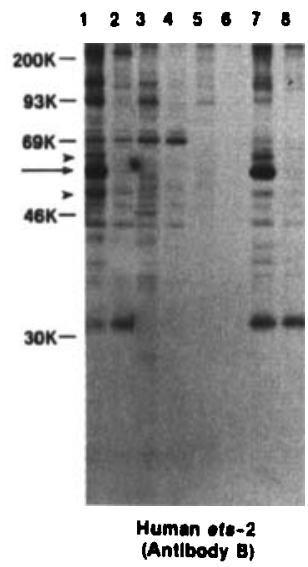

FIGURE 10. Subcellular localization of the chicken ets, human ets-1 and human ets-2 proteins. (A) Thymus cells prepared from 2-week-old chickens were labeled with $\left[{ }^{35} \mathrm{~S}\right]$ methionine $(200 \mu \mathrm{Ci} / \mathrm{ml}, 1 \mathrm{~h})$ and after washes in cold phosphate buffered saline, the cells were gently homogenized in isotonic low salt buffer ( $20 \mathrm{mM}$ HEPES, $0.25 \mathrm{M}$ sucrose, $5 \mathrm{mM} \mathrm{KCl}, 5$ $\mathrm{mM} \mathrm{MgCl}, 0.5 \% \mathrm{NP}-40,0.1 \%$ sodium deoxycholate, $1.0 \%$ aprotinin, $0.4 \mathrm{mM} \mathrm{PMSF}, 0.01$ $\mathrm{mM}$ TLCK, $0.1 \mathrm{mM}$ TPCK) and nuclei were pelleted by centrifugation at $1000 \times \mathrm{g}$ for $5 \mathrm{~min}$ at $4^{\circ} \mathrm{C}$. The crude-cytoplasm was further fractionated by ultracentrifugation $(100,000 \times \mathrm{g})$ and the clarified cytoplasm and the membrane pellet were obtained. The nuclear pellet was washed once with the isotonic low salt buffer, after centrifugation at $1000 \times \mathrm{g}$ the nuclear wash fraction and the crude nuclei were obtained. The lysis of cells and nuclear isolation were monitored by phase-contrast microscopy. After ultracentrifugation, each fraction was adjusted to RIPA buffer conditions, and extracts (equivalent to $5 \times 10^{7}$ cells) were immunoprecipitated with Antibody B. Immunoprecipitation of the total cell extract (Panel A, lanes 1 and 2), cytoplasmic compartment (lane 3), membrane compartment (lane 4) and nuclear compartment (lane 5) are shown. Completion of Antibody B with the ets-1-ets-2 peptide is in lane 1, and the arrow indicates the chicken ets protein. (B) Similarly, the P3HR-1 cells were fractionated. The total extract (lanes 1 and 2), the cytoplasmic compartment (lanes 3 and 4), the membrane compartment (lanes 5 and 6 ) and nuclear component (lanes 7 and 8 ), each representing $5 \times 10^{6}$ cells, were immunoprecipitated with Antibody $A$. The competition with the ets-1 peptide is shown in lanes 2, 4,6 and 8 and the arrow indicates the ets-1 protein. (C) The human COLO 320 DM cells were fractionated, as above. The total extract (lanes 1 and 2), cytoplasmic compartment (lanes 3 and 4), membrane compartment (lanes 5 and 6) and nuclear compartment (lanes 7 and 8 ), each presenting $5 \times 10^{6}$ cells, were immunoprecipitated with Antibody B. Competition with the ets-1-ets-2 peptide is shown in lanes 2, 4, 6 and 8 and the arrow indicates the ets-2 protein.

and $e t s$ - 2 domains are in the same protein, the localization of the ets gene product may depend on other factors. Unlike the variant locations of human ets proteins, we find that the chicken ets gene product is equally distributed between the cytoplasmic and nuclear subcellular fractions; this observation would seem to be consistent with the known genetic organization of both ets domains in the avian genome. ${ }^{9,13}$ It is possible, too, that the avian ets protein, in response to some physiological event, shuttles between the cytoplasm and nucleus, whereupon each domain is able to exert its distinctive activity.

Both ets-1 and ets-2 domains may be of potential interest in oncology. The transposition of these genes in nonrandom translocations found in specific leukemias, 
as well as in their associated altered expression, suggests that both ets-1 and ets-2 genes may be involved in human hematopoietic neoplasias. ${ }^{25}$ Differential expression of ets proteins could provide useful molecular markers for the characterization of hematopoietic tumors.

Having established that the human genome contains two distinct loci with homology to the viral ets gene, $\mathrm{Hu}$-ets-1 and $\mathrm{Hu}-e t s-2$, made it possible to precisely map their locations onto their respective human chromosomes. Employing both somatic cell hybrid studies and in-situ chromosomal techniques, we have localized the human proto-ets-1 and proto-ets-2 domains to the human chromoscmes, $11 \mathrm{q} 23$ and $21 \mathrm{q} 22$, respectively. ${ }^{26}$

A number of leukemias of myelomonocytic lineage show chromsome abnormalities in the very region where the human ets loci reside. In fact, the $11 \mathrm{q} 23$ region where the Hu-ets-1 locates is known to be involved in a number of translocations associated with acute myeloid leukemias. We have, therefore, focused primarily on the $t(4 ; 11)(q 21 ; q 23)$ translocation, an aberration that is associated with a rare infant leukemia of the undifferentiated type (AUL) thought to be congenital, and could perhaps involve the Hu-ets-1 locus. Similarly, we investigated the $t(8 ; 21)(q 22 ; q 22)$ translocation, associated with a subtype of acute myelogenous leukemia (AML-M2) involving the $21 \mathrm{q} 22$ chromosomal region, where Hu-ets-2 is located (FIG. 11).

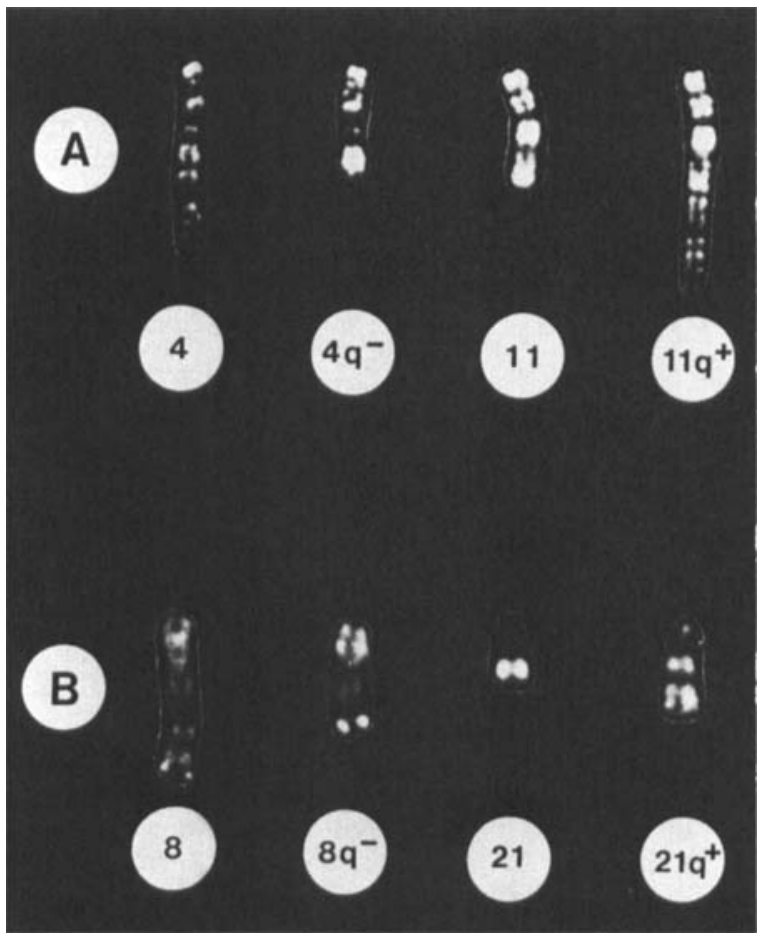

FIGURE 11. Partial karyotype analysis showing the normal and recombinant chromosomes resulting from: (A) the reciprocal translocation $t(4 ; 11)(q 21 ; q 23)$, and (B) the reciprocal translocation $\mathrm{t}(8 ; 21)(\mathrm{q} 22 ; \mathrm{q} 22)$. 
From Southern blot studies using genomic DNA samples derived from cell hybrids containing the recombinant chromosomes derived from these translocations, we have found that the Hu-ets-1 gene does in fact translocate from chromosome 11 to 4, while the Hu-ets-2 gene was found to transpose from chromosome 21 to $8 .^{27}$ Using in-situ hybridization, other workers have shown, with gene probes for $\gamma$-interferon and v-ets by hybridizing them to metaphase chromosomes obtained from three patients with AML having the chromosomal translocation $t(9 ; 11)(\mathrm{p} 22 ; \mathrm{q} 23)$, that the proto-ets- 1 gene was translocated from chromosome 11 to the short arm of chromosome 9 adjacent to the interferon genes. ${ }^{28}$ Such studies reinforce the supposition that juxtapositioning of the proto-ets genes next to other cellular genes may lead to their dysregulation. Further, the translocations we have observed appear to affect the transcription patterns of both Hu-ets genes; these were confirmed by Northern blot studies on RNA derived from leukemic and control samples, as well as from continuous cell lines derived from patients. In such comparative studies, albeit on limited samples, we have found that in $t(4 ; 11)$ leukemic cells significantly lower levels of Hu-ets-1 mRNA were present. Similarly, studies on $t(8 ; 21)$ AML samples revealed that not all the species of Hu-ets-2 mRNA known to be present in normal lymphocytes and other human cells were present. Particularly absent, or markedly reduced, was the larger 4.7-kb species of human ets-2 mRNA, suggesting that this alteration of expression of human ets mRNA in leukemia patient samples may arise as a consequence of the specific position effects sustained (FIG. 12).

The significance of these studies and their specificity was further reinforced by utilizing our Hu-ets-1 probe to show that the ets-1 gene was not transposed in the $(11 ; 22)(q 12 ; q 23)$ translocation of Ewing sarcoma, in contrast to the $(4 ; 11)$ translocation noted previously. However, in neither case was there any evidence that the human ets-1 or ets-2 genes were rearranged, although the precise breakpoints and their location relative to these proto-oncogenes remains to be determined. Such proto-ets gene relocations may well play a critical role in altering the regulation of these unique genes for certain specific leukemias; any altered products arising from such translocations may serve as useful diagnostic or prognostic markers in these specific pathologies. $^{29}$

The $21 \mathrm{q} 22$ region or, specifically, the $21 \mathrm{q} 22.3$ region, where Hu-ets-2 has been physically and genetically mapped, seems to be relevant not only to cancer but to other human cytogenetic pathologies as well. This region is the precise region that when trisomic appears to confer the Down's syndrome (DS). DS afflicts 1 out of 600 newborns, and such individuals display a number of dismorphic features and developmental abnormalities, including mental retardation. ${ }^{30}$ The causes of trisomy of the 21 q22.3 region are mainly due to the trisomy of the entire chromosome 21 . Very rarely, but significantly, a microduplication of the q22.3 region or inheritance of this region attached to an autosome (partial trisomy) may be the cause of the DS phenotype. Such rare individuals, therefore, may prove to be very informative for defining the minimal genetic region required for the appearance of DS. Since we know that the Hu-ets-2 gene locates in this region, studies with this probe may become quite valuable for the initiation of molecular cloning studies necessary to identify and isolate the entire region responsible for DS. Furthermore, preliminary data shows three copies of the ets-2 gene in some of these rare DS patients using an ets-2-specific probe cloned in our laboratory. ${ }^{31}$ Significantly, DS patients show a higher incidence of leukemia, as well as precocious neurological signs of Alzheimer's disease. ${ }^{30}$ Having a specific antibody for the human ets-2 proteins available will permit us to evaluate and precisely quantitate the expression of this gene in both Down's syndrome and Alzheimer's disease.

Finally, restriction fragment-length polymorphisms (RFLPs) for the ets-2 gene have been used as genetic markers to study whether or not the genetic constitution 


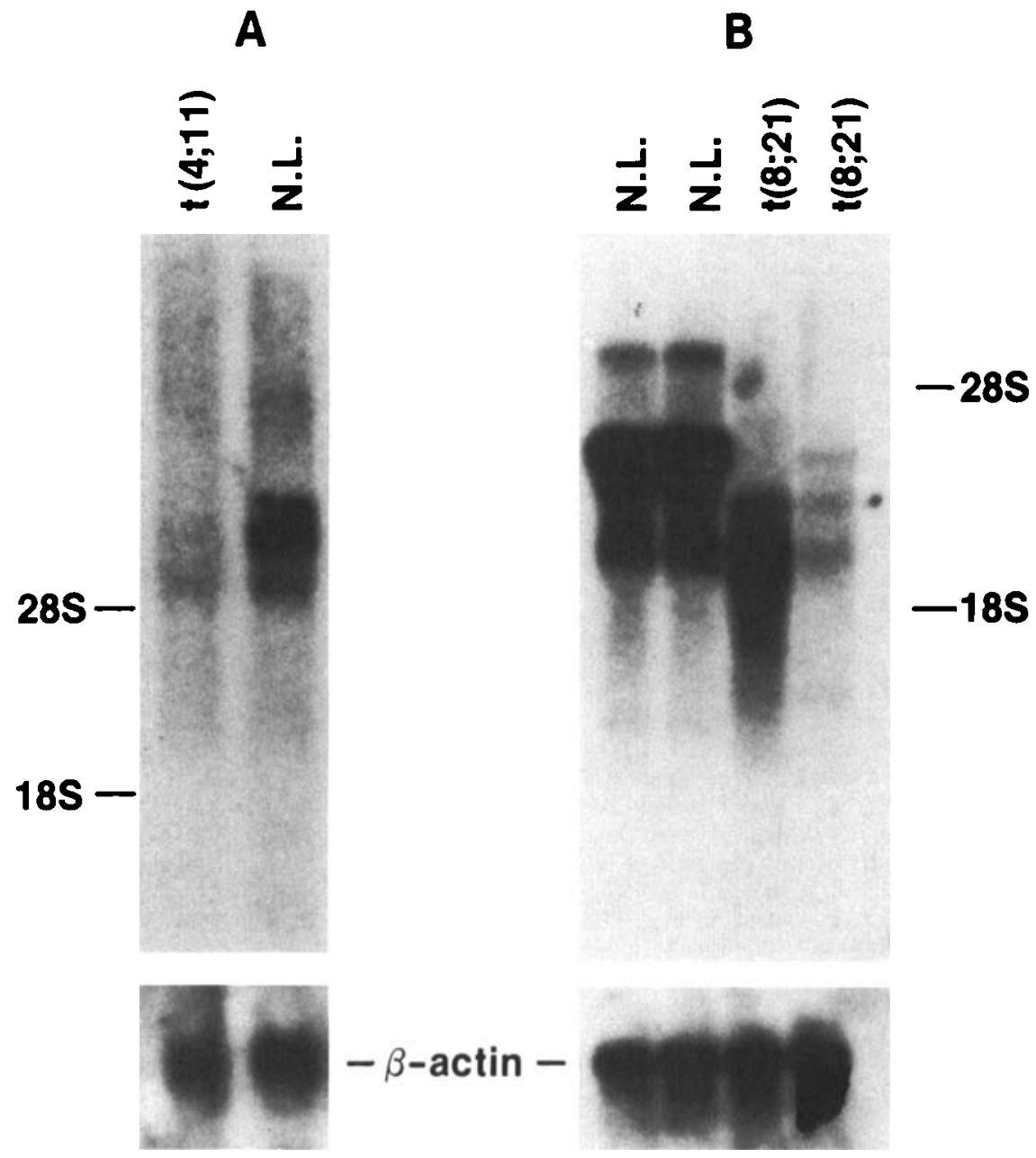

FIGURE 12. Northern blot analysis of total RNA extracted from: (A) blast cells derived from a $t(4 ; 11)$ AUL patient and normal lymphocytes (N.L.), and (B) blast cells derived from two $\mathrm{t}(8 ; 21) \mathrm{AML}-\mathrm{M} 2$ patients and normal lymphocytes. In all cases, total RNA was extracted by the guanidinium/cesium chloride method and was resolved on $1.2 \%$ formaldehyde-agarose gels. Hybridization was performed under stringent conditions (2b) with: (A) ets-1 (RD6K) and (B) ets-2 (H33) probes. The same blots (bottom) were rehybridized using an $\alpha$-actin cDNA probe in order to compare relative amounts of RNA in these samples.

(haplotype) of the chromosome 21 that undergoes normal, meiotic disjunction is different from the haplotype of chromosome 21 that is not undergoing disjunction and therefore predisposing to the trisomy associated with Down's syndrome. The results of our extensive survey with the Hu-ets-2 probe, performed on families with a Down's syndrome child, shows that all examples of chromosome 21 are genetically similar, thus indicating that haplotype analysis of chromosome 21 is not applicable to the 
prevention of this syndrome. ${ }^{32}$ This finding is important since on the basis of a previous study the clinical relevance of similar chromosomal haplotype tests was suggested. ${ }^{33}$ According to our experience, such tests should be viewed with extreme caution and reservation.

\section{REFERENCES}

1. Duesberg, P. H., M. Nunn, N. Kan, D. Watson, P. H. Seeburg \& T. Papas. 1985. Are activated proto-onc genes cancer genes? In Modern Trends in Human Leukemia VI. R. Neth, R. C. Gallo, M. F. Greaves \& G. Janka, Eds. Vol. 29: 9-27. Springer-Verlag. Berlin.

2. Garrett, C. T. 1986. Critical review: Oncogenes. Clin. Chim. Acta 156: 1-40.

3. Mitleman, F. 1984. Restricted number of chromosomal regions implicated in aetiology of human cancer and leukemia. Nature 310: 325-327.

4. ascione, R., N. Sacchi, D. K. Watson, R. J. Fisher, S. Fujiwara, A. Seth \& T. S. PAPAS. 1986. Oncogenes: Molecular probes for clinical application in malignant diseases. Gene Anal. Tech. 3: 25-39.

5. Nunn, M. F., P. H. Seeburg, C. Moscovici \& P. H. Duesberg. 1983. Tripartite structure of the avian erythroblastosis virus E26 transforming gene. Nature 306: 391-395.

6. Leprince, D., A. Gegonne, J. Coll, C. De TAisne, A. Schneeberger, C. Lagrou \& D. STEHELIN. A putative second cell-derived oncogene of the avian leukemia retrovirus E26. Nature 306: 395-397.

7. Bister, K., M. Nunn, C. Moscovici, B. Perbal, M. A. Baluda \& P. H. Duesberg. 1982. Acute leukemia viruses E26 and avian myeloblastosis virus have related transformationspecific RNA sequences but different genetic structures, gene products, and oncogenic properties. Proc. Natl. Acad. Sci. USA 79: 3677-3686.

8. Papas, T.S., D. G. Blair, R. J. Fisher, D. K. Watson, N. Sacchi, S. Fujiwara, N. Bhat \& R. Ascione. The ets genes. In The Oncogene Handbook. E. P. Reddy, T. Curran \& A. Skalka, Eds. Elsevier. New York, NY. In press.

9. Watson, D. K., M. J. McWilliams-Smith, C. S. Flordellis \& T. S. Papas. 1986. The pl35 transforming protein of E26 is not coterminal with the chicken proto-ets gene product. In Advances in Gene Technology: Molecular Biology of the Endocrine system. D. Puett, F. Ahmad, S. Black, D. M. Lopez, M. H. Melner, W. A. Scott \& W. J. Whelan, Eds. 158-159. Cambridge University Press. Cambridge.

10. Watson, D. K., M. J. McWilliams-Smith, M. F. NunN, P. H. Duesberg, S. J. O'Brien \& T.S. PAPAS. 1985. The ets sequence from the transforming gene of avian erythroblastosis virus, E26, has unique domains on human chromosomes 11 and 21: Both loci are transcriptionally active. Proc. Natl. Acad. Sci. USA 82: 7294-7298.

11. Watson, D. K., M. J. Smith, C. Kozak, R. Reeves, J. Gearhart, M. F. Nunn, W. Nash, J. R. Fowle III, P. Duesberg, T. S. Papas \& S. J. O'Brien. 1986. Conserved chromosomal positions of dual domains of tl:e ets proto-oncogene in cats, mice and man. Proc. Natl. Acad. Sci. USA 83: 1792-1796.

12. Pribyl, L. J., D. K. Watson, M. J. McWilliams, R. Ascione \& T. Papas. Characterization of the ets-2 gene in Drosophila melanogaster. In Advances in Gene Technology: The Molecular Biology of Development, ICSU Short Reports. In press.

13. WATSON, D. K., M. J. MCWilliams \& T. S. PAPAS. Molecular structure of the avian and mammalian ets genes. In Oncology and Immunology of Down's Syndrome. Alan R. Liss, Inc. New York, NY. In press.

14. Bhat, N. K., R. J. Fisher, S. Fujiwara, R. ascione \& T. S. Papas. Temporal and tissue-specific expression of mouse ets genes. Proc. Natl. Acad. Sci. USA. In press.

15. Fujiwara, S., R. J. Fisher, A. Seth, N. K. Bhat, N. Sacchi \& T. S. Papas. The products of the human homologs of the v-ets oncogene: ets-1, a cytoplasmic $51 \mathrm{KDa}$ protein and ets-2, a nuclear $56 \mathrm{KDa}$ protein. Science. In press.

16. Bhat, N. K., R. J. Fisher, S. Fujiwara, R. Ascione \& T. S. Papas. Differential regulation of ets loci during murine hepatic regeneration. In Advances in Gene Technology: The Molecular Biology of Development, ICSU Short Reports. In press.

17. Higgins, G. M. \& R. M. ANDERSON. 1931. Experimental pathology of the liver. I. 
Restoration of the liver of the white rat following partial surgical removal. Arch. Pathol. 12: $186-202$.

18. BUCHLER, N. L. R. 1971. Liver regeneration. In Regeneration of Liver and Kidney. 17-176. Little Brown \& Co. Boston, MA.

19. Curran, T., R. Bravo \& R. Muller. 1985. Transient induction of $\mathrm{c}$-fos and c-myc is an immediate consequence of growth factor stimulation. Cancer Surv. 4: 655-681.

20. DenhardT, D. T., D. R. Edwards \& C. L. J. Parfetr. 1986. Gene expression during mammalian cell cycle. Biochim. Biophys. Acta 865: 83-125.

21. Fujiwara, S., R. J. Fisher, A. Seth, N. K. Bhat \& T. S. Papas. 1987. Human ets-1 and ets-2 proteins: Identification and intracellular localization. In Advances in Gene Technology: The Molecular Biology of Development. R. W. Vollellmy et al., Eds. ICSU Short Reports 7: 77.

22. Chen, Z.-Q., N. C. Kan, L. Pribyl, J. Lautenberger, E. Moudrianakis \& T. S. Papas. Proto-oncogene c-ets of sea urchins: Transcripts and sequence homology with v-ets and human c-ets genes. In Advances in Gene Technology: The Molecular Biology of Development. ICSU Short Reports. In press.

23. Evans, G. I. \& D. C. HANCOCK. 1985. Studies on the interaction of the human c-myc protein with cell nuclei: $\mathrm{p} 62^{\mathrm{cm} \mathrm{ms}}$ as a member of a discrete subset of nuclear proteins. Cell 43: 253-261.

24. Dingwall, C. \& R. A. Laskey. 1986. Protein import into the cell nucleus. In Ann. Rev. Cell Biol. G. E. Palade, B. M. Alberts \& J. A. Spudich, Eds. Vol. 2: 367-390.

25. Sacchi, N., D. K. Watson, A. H. M. G. van Kessel, A. Hagemeijer, H. D. Drabkin, D. PATterson \& T. S. PAPAS. 1986. Hu-ets-1 and Hu-ets-2 genes are transposed in acute myeloid leukemias with $(4 ; 11)$ and $(8 ; 21)$ translocations. Science 231: 379-382.

26. Drabkin, H. D., M. Van Keuren, I. Hart, P. Duesberg, N. Sacchi, T. Papas \& D. PATterson. 1986. Precise localization of the Hu-ets-2 gene to the critical region of chromosome 21 in $\mathrm{t}(8 ; 21) \mathrm{AML}$ and Down's syndrome. In Advances in Gene Technology: Molecular Biology of the Endocrine System. D. Puett, F. Ahmad, S. Black, D. M. Lopez, M. H. Meener, W. A. Scott \& W. J. Whelan, Eds. 112-113. Cambridge University Press. Cambridge.

27. LeBeau, M. M., J. D. Rowley, N. Sacchi, D. K. Watson, T. S. Papas \& M. O. Diaz. 1986. Hu-ets-2 is translocated to chromosome 8 in the $t(8 ; 21)$ of acute myelogenous leukemia. Cancer Genet. Cytogenet. 23: 269-274.

28. LeBeau, M. M., P. Pitha \& J. D. Rowley. 1986. Interferon and c-ets-1 genes in the translocation $(9 ; 11)(\mathrm{p} 22 ; \mathrm{q} 23)$ in human acute monocytic leukemia. Science 231: $265-$ 267.

29. Papas, T. S., D. K. Watson, N. Sacchi, S. O'Brien \& T. S. Papas. The cellular ets genes: Molecular probes in human neoplasia. In Proceedings of International Advanced Course of Human Pre-Leukemia. Rome, Italy, Nov. 13-17, 1985.

30. SMITH, G. F., Ed. 1985. In Molecular Structure of the Number 21 Chromosome and Down's Syndrome Ann. N. Y. Acad. Sci. Vol. 450.

31. Sacchi, N., J. M. Delabar \& T. S. Papas. Unpublished observations.

32. Sacchi, N., J. F. Gusella, L. Perroni, F. Dagna Bricarelli \& T. S. Papas. Molecular haplotypes of chromosome 21 are not indicative of predisposition to Down's syndrome. Submitted for publication.

33. antonarakis, S. E., S. D. Kittur, C. Metaxotou, P. C. Watkins \& A. S. Patel. 1985. Analysis of DNA haplotypes suggests a genetic predisposition to trisomy 21 associated with DNA sequences on chromosome 21. Proc. Natl. Acad. Sci. USA 82: 3360-3364.

34. LAEMMLI, U. K. 1970. Cleavage of structural proteins during the assembly of the head of bacteriophage T4. Nature (London) 227: 680-685.

35. BONNER, W. \& R. LASKY. 1974. A film detection method for tritium-labelled proteins and nucleic acid in polyacrylamide gels. Eur. J. Biochem. 46:83-88.

36. Cleveland, D. W., S. G. Fisher, M. W. Kirschner \& U. K. Laemmli. 1977. Peptide mapping by limited proteolysis in SDS and analysis by gel electrophoresis. J. Biol. Chem. 252: $1102-1106$. 